\title{
Sustainability of Groundwater for Irrigation Purposes in Semi-arid Parts of Namibia
}

\author{
Hilma Rantilla Amwele ${ }^{1 * t}$, Nnenesi Anna Kgabi ${ }^{2 \dagger}$ and Liisa Indileni Kandjibi ${ }^{1}$ \\ ${ }^{1}$ Department of Agriculture and Natural Resources Sciences, Namibia University of Science and Technology, Windhoek, \\ Namibia, ${ }^{2}$ Unit for Environmental Science and Management, North-West University, Potchefstroom, South Africa
}

The groundwater quality data from 1,137 boreholes in 10 regions of Namibia were assessed for sodium adsorption ratio (SAR), Kelly's ratio (KR), sodium percentage (Na\%), magnesium adsorption ratio (MAR), total hardness $(\mathrm{TH})$, soluble sodium percentage (SSP), potential salinity (PS), electrical conductivity (EC), and total dissolved solids (TDS) to determine the suitability for the irrigation. The groundwater was classified as follows:

OPEN ACCESS

Edited by: Janez Susnik,

IHE Delft Institute for Water

Education, Netherlands

Reviewed by:

Emmanuel Daanoba Sunkari,

University of Mines and

Technology, Ghana

Yuchuan Wang

Northwest A\&F University, China

*Correspondence:

Hilma Rantilla Amwele

hamwele@nust.na

TORCID:

Hilma Rantilla Amwele orcid.org/0000-0003-1619-6813

Nnenesi Anna Kgabi orcid.org/0000-0001-9488-9661

Specialty section:

This article was submitted to

Water and Human Systems,

a section of the journal

Frontiers in Water

Received: 30 August 2021 Accepted: 01 November 2021 Published: 06 December 2021

Citation:

Amwele HR, Kgabi NA and Kandjibi LI (2021) Sustainability of Groundwater for Irrigation Purposes in Semi-arid

Parts of Namibia.

Front. Water 3:767496.

doi: 10.3389/frwa.2021.767496 all the regions' groundwater shows the TH as very hard water of $>4.6 \mathrm{meq} / \mathrm{I}, \mathrm{PS}$ as not suitable for irrigation (>3 meg/l), and EC as very highly (0.75-2.25 dS/m). However, Na\%: $10 \%$ of regions have doubtful water (>80\%), MAR: $30 \%$ of regions are not recommended for irrigation (>50 meq/l), and TDS: $90 \%$ of the regions have slightly moderate (450-2,000 $\mathrm{mg} / \mathrm{l})$ and $10 \%$ have groundwater that is unsuitable for agricultural purposes ( $>2,000$ $\mathrm{mg} / \mathrm{l})$. The unsuitability of groundwater for irrigation could be due to higher concentrations of $\mathrm{K}^{+}, \mathrm{Mg}^{2+}, \mathrm{Ca}^{2+}$, and $\mathrm{Cl}^{-}$that has exceeded the $\mathrm{FAO}$ guideline for irrigation. Some groundwater qualities had inverse classification such as SAR all regions have excellent groundwater (<10 meq/l), KR: $90 \%$ of regions have safe water ( $<1 \mathrm{meq} / \mathrm{l})$, Na\%: 50\% of regions have good groundwater (20-40\%), 40\% of the regions have permissible water (40-80\%), and MAR: $+70 \%$ of region's water is recommended for irrigation ( $<50$ meq/l).

Keywords: groundwater, irrigation, suitability for irrigation, water quality, salinity

\section{INTRODUCTION}

Groundwater has become the major source of water in the agricultural sector for many countries, where climate change is coupled with the rapid growth of the population and the insufficient river water and drainage systems are seen as major problems (Rawat et al., 2018). Therefore, poor groundwater quality for irrigation purposes has become a matter of concern in recent years (Hopkins et al., 2007). Groundwater helps greatly in improving the efficiency of the water use in both rain-fed areas and in irrigation areas which can accommodate far greater variability in demand from famers, particularly during drought or dry season when irrigation water may be needed most (Bauder et al., 2008).

In Namibia, rainfall is limited and surface water is only available during the rainy season. Although surface water is only available during the rainy season, these water sources normally dry up very quickly due to Namibia's high temperature. The prevailing high temperatures in the Namibian regions do not only affect the availability of surface water but also impact both the chemicals and biological characteristics of surface water (Akpan-Idiok et al., 2012). The higher temperature also affects the amount of water that infiltrates and recharges the groundwater (Jannis et al., 2021). 
Shah and Mistry (2013) stated that the suitability of groundwater for irrigation purposes depends on the nature of the mineral elements in the water. Sodium adsorption ratio (SAR), Kelly's ratio (KR), sodium percentage ( $\mathrm{Na} \%)$, magnesium adsorption ratio (MAR), total hardness $(\mathrm{TH})$, soluble sodium percentage (SSP), potential salinity (PS), electrical conductivity (EC), and total dissolved solid (TDS) are the most important water quality criteria, which determine the water quality and suitability for irrigation use (Meireles et al., 2010).

Agriculture plays an important role in the Namibian economy and the life of its people. Freshwater scarcity in Namibia has become a major issue, and this has affected crop production and other agricultural activities mostly in semiarid and arid regions. The country's annual rainfall figures range from 550 to $600 \mathrm{~mm}$ in the far northeast and between 250 and $300 \mathrm{~mm}$ in the south of the country. The central part of Namibia, which hosts the capital city Windhoek, has annual rainfall figures ranging between 450 and $500 \mathrm{~mm}$. The northern part of Namibia referred to as Cuvelai extends to the border of Southern Angola and has an annual rainfall ranging between 250 and $350 \mathrm{~mm}$. The eastern part of the country, which also hosts the Kalahari Desert, receives between 50 and $250 \mathrm{~mm}$ of rainfall. The coastal part of Namibia which is largely a desert and stretches from Oranjemund in the south to Kunene in the northwest receives $<50 \mathrm{~mm}$ of rainfall (NamWater, 2021).

According to Christelis and Struckmeier (2011), "Fortyeight $(48 \%)$ of Namibia is covered by porous unconsolidated superficial deposits and the rest of the country is completely underlain by consolidated rocks that have various degrees of fracturing, including karstification in some calcareous rocks (Figure 1). Groundwater conditions are unfavorable over the large part of the country because of limited water availability; low and unreliable recharge; low groundwater (borehole) yields; deep water tables; poor groundwater quality; or high risk of contamination. Fifty-eight (58\%) of the country is covered by low permeability rocks and are categorized as aquitards and aquicludes. Aquitards the groundwater (borehole) yields between 0.5 and $3 \mathrm{~m}^{3} / \mathrm{h}$ and aquicludes the groundwater (borehole) yields are $<0.5 \mathrm{~m}^{3} / \mathrm{h}$. Twenty-six $(26 \%)$ of the country is underlain by porous aquifers and $16 \%$ by fractured rock aquifers. In addition, highly productive aquifers are categorized as those with average groundwater (borehole) yields $>15 \mathrm{~m}^{3} / \mathrm{h}$ and it occurs over $3 \%$ of the country $\left(14,000 \mathrm{~km}^{2}\right)$ and most of these areas have been declared as groundwater control areas. It is estimated that on average only $1 \%$ of annual rainfall contributes to groundwater recharge."

Evaporation rates are very high all over the country, ranging from $<1,680 \mathrm{~mm} / \mathrm{a}$ in the northeast to more than $2,660 \mathrm{~mm} / \mathrm{a}$ in the south; thus, it exceeds precipitation by far (Stefan et al., 2008). Annual evaporation ranges from $2,600 \mathrm{~mm}$ in the northeast to $3,700 \mathrm{~mm}$ in the central southern area. Evaporation is highest during the months of October to December where dams in Namibia can lose between 20 and $85 \%$ of their water through evaporation within one season (NamWater, 2021). Because of higher evaporation rates, the water availability and quality for human consumption, agriculture, and aquaculture production in the country are affected and in some areas the water becomes very salty especially during the dry or drought period.

The main objective of the study was to assess the suitability of groundwater quality in Namibian regions for irrigation use.

\section{MATERIALS AND METHODS}

\section{Study Area}

The samples were collected from different Namibian regions as follows: 155 boreholes from Erongo region, 72 boreholes from Hardap region, 230 boreholes from Karas region, 142 boreholes from Kavango region, 11 boreholes from Khomas region, 212 boreholes from Kunene region, 51 boreholes from Ohangwena region, 81 boreholes from Omaheke region, 104 boreholes from Otjozondjupa region, and 72 boreholes from Zambezi region.

\section{Data Collection}

Secondary data used in this study were collected from 1,137 groundwater boreholes from 10 Namibian regions logged by the Ministry of Agriculture Water and Land Reform. The QGIS 3.4.0 software was used to generate the borehole distribution map in different regions (Figure 2).

\section{Laboratory Analysis}

The water samples were tested by Analytical Laboratory Services, Windhoek, Namibia, and the analysis was based on AWWAs standard methods for the examination of water and wastewater.

\section{Irrigation Water Quality Assessment}

The following elements such as EC, TDS, $\mathrm{SO}_{4}^{2-}, \mathrm{Cl}^{-}, \mathrm{Ca}^{+}, \mathrm{Mg}^{+}$, and $\mathrm{Na}^{+}$were tested in groundwater samples. Irrigation water quality was calculated by SAR, KR, Na\%, MAR, TH, SSP, PS, EC, and TDS to classify the suitability of groundwater for irrigation use as follows:

Sodium adsorption ratio (SAR) was used to estimate the potential of $\mathrm{Na}^{+}$to accumulate in the soil primarily (water movement) at the expense of $\mathrm{Ca}^{2+}$ and $\mathrm{Mg}^{2+}$ because of regular use of sodic water (Bhat et al., 2016). SAR is calculated and classified as follows (Table 1):

$$
\mathrm{SAR}=\frac{\mathrm{Na}^{+}}{\sqrt{\mathrm{Ca^{2+ } + M g ^ { 2 + } / 2}}}
$$

where:

$\mathrm{Na}^{+}$-sodium, $\mathrm{Ca}^{2+}$-calcium, and $\mathrm{Mg}^{2+}$-magnesium, all in miliequivalents per liter (meq/l).

Kelly's ratio (KR) was used to determine the salinity level based on the concentration of sodium against calcium and magnesium in the borehole water. When an excessive amount of sodium reacts with calcium and magnesium in irrigation water, it causes toxic materials that result in poor water quality, and this affects plant growth rate and yield (Jaji et al., 2007). KR is calculated and classified as follows (Table 2):

$$
\mathrm{KR}=\frac{\mathrm{Na}^{+}}{\mathrm{Ca}^{2+}+M g^{2+}}
$$

where: 


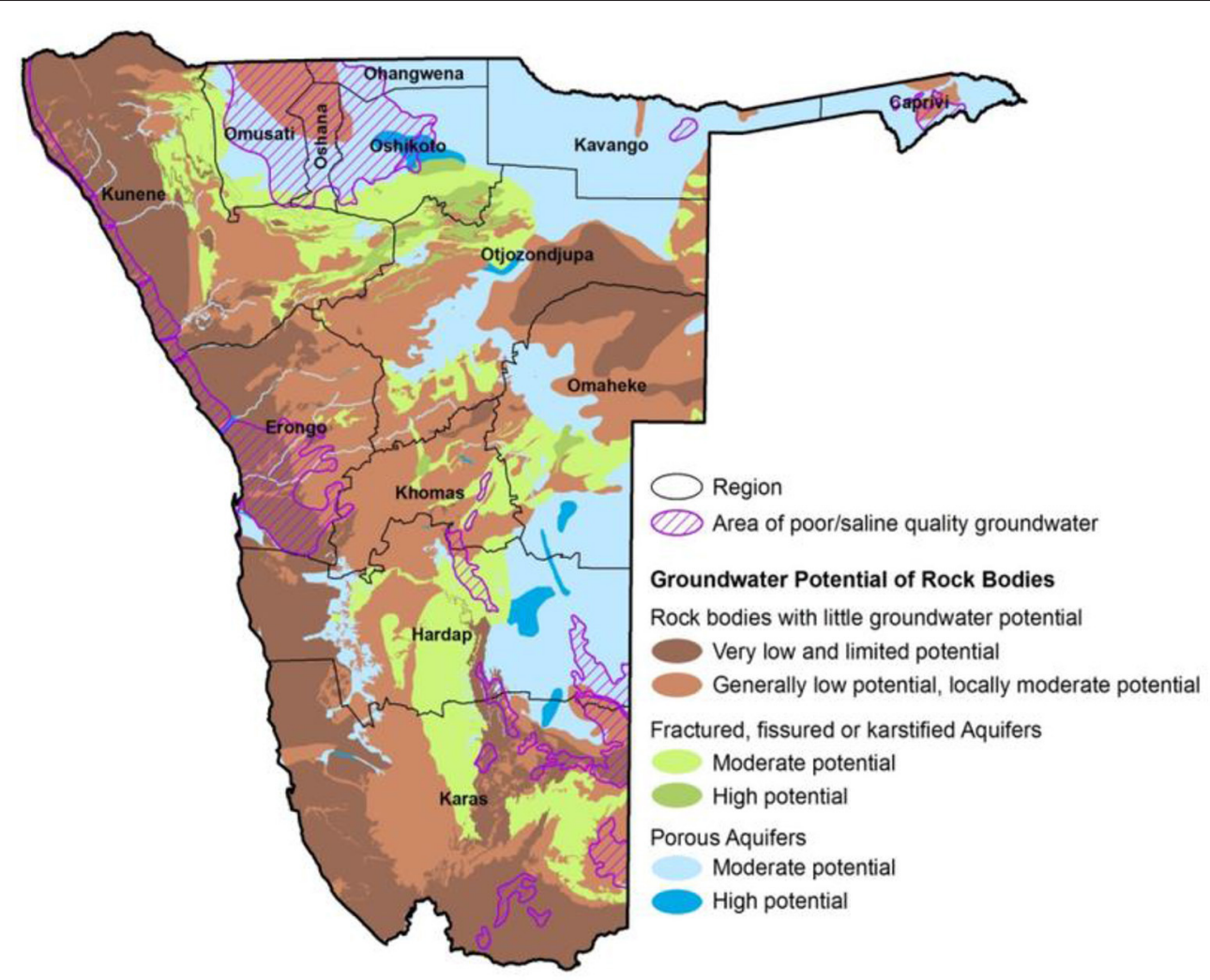

FIGURE 1 | Hydrogeological map of Namibia. Source: Christelis and Struckmeier (2011).

$\mathrm{Na}^{+}$-sodium, $\mathrm{Ca}^{2+}$-calcium, and $\mathrm{Mg}^{2+}$-magnesium, all in miliequivalents per liter (meq/l).

Sodium percentage ( $\mathbf{N a} \%)$ was used to determine the salinity level based on the concentration of sodium and potassium against calcium and magnesium. When the concentration of sodium and potassium in water is high, it removes calcium and magnesium ions, which reduces the water movement capacity (Yisa et al., 2012). The sodium percentage is calculated and classified as follows (Table 3):

$$
\mathrm{Na} \%=\frac{\mathrm{Na}^{+}+K^{+}}{\mathrm{Ca}^{2+}+M g^{2+}+N a^{+}+K^{+}} \times 100
$$

where:

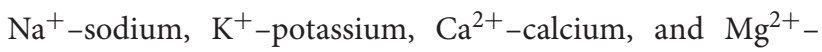
magnesium, all in miliequivalents per liter (meq/l).

Magnesium adsorption ratio (MAR) was used to determine the salinity level based on the concentration of magnesium against calcium (magnesium hazardous). When the concentration of magnesium against calcium in irrigation water is high, it increases water $\mathrm{pH}$ (Bucks et al., 2009). MAR is calculated and classified as follows (Table 4):

$$
\operatorname{MAR}=\frac{M g^{2+}}{C a^{2+}+M g^{2+}} \times 100
$$

where:

$\mathrm{Ca}^{2+}$-calcium and $\mathrm{Mg}^{2+}{ }_{-}$magnesium, all in miliequivalents per liter (meq/l).

Total hardness (TH) was used to determine the salinity level based on the concentration of calcium against magnesium in water. A high concentration of calcium against magnesium affects the water quality. It causes water hardness which affects the distribution of water from water supply systems to crops (Bucks et al., 2009). Total hardness is calculated and classified as follows (Table 5):

$$
\mathrm{TH}=2.497 \times \mathrm{Ca}^{2+}+4.005 \times \mathrm{Mg}^{2+}
$$

where $\mathrm{Ca}^{2+}$-calcium and $\mathrm{Mg}^{2+}$-magnesium, all in miliequivalents per liter (meq/l).

Soluble sodium percentage (SSP) was used to determine the salinity level based on the concentration of sodium against calcium and magnesium. A high concentration of sodium against calcium and magnesium in water causes toxicity substances, which results in burned leaves and dead plant tissues (Bhat et al., 2016). SSP is calculated and classified as follows (Table 6):

$$
\mathrm{SSP}=\frac{\mathrm{Na}^{+} \times 100}{\mathrm{Ca}^{2+}+\mathrm{Mg}^{2+}+\mathrm{Na}^{+}}
$$

where: 


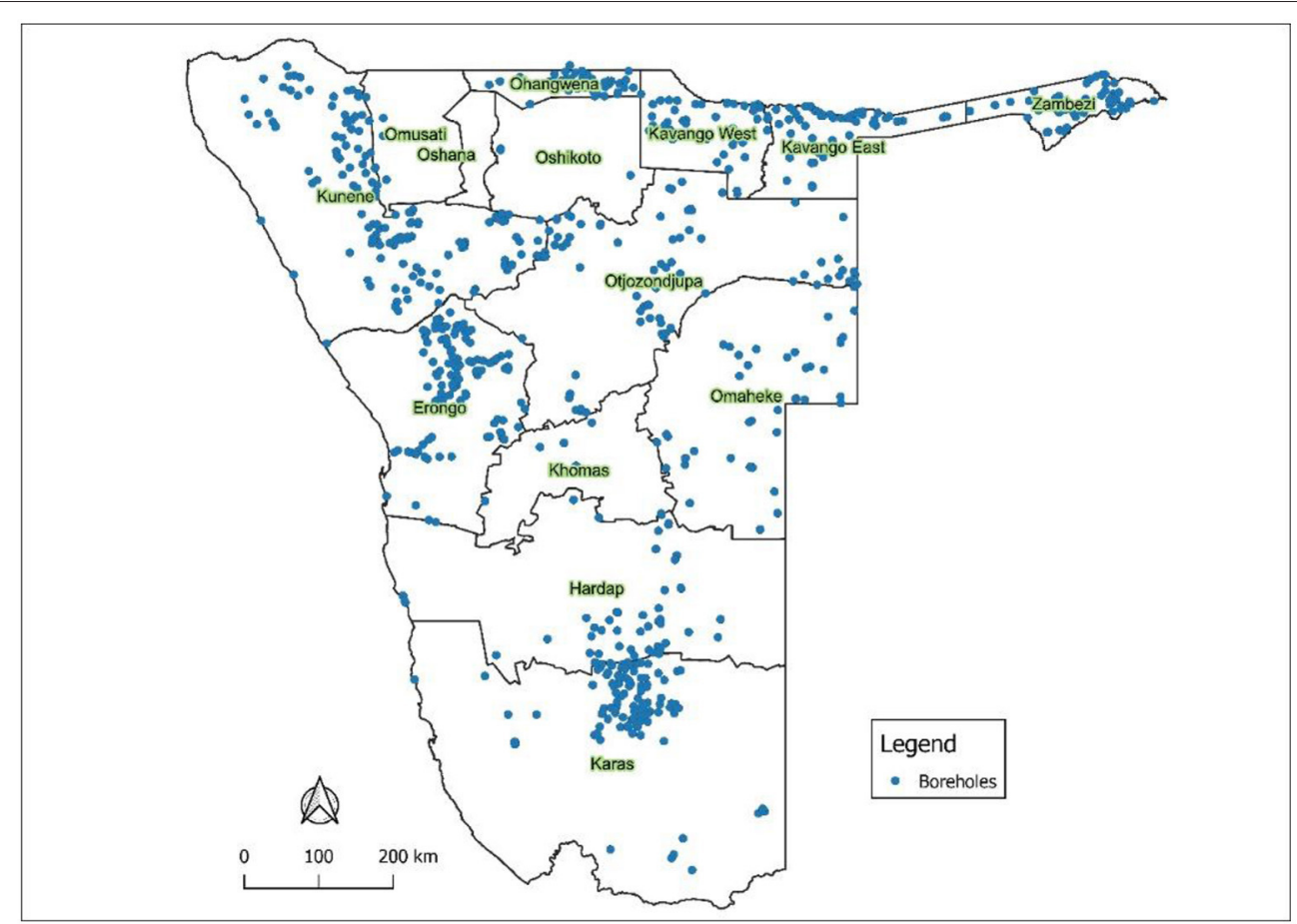

FIGURE 2 | Borehole distribution map of Namibia (2008-2014). Source: Nzuma (2021).

TABLE 1 | Classification of groundwater quality based on SAR.

\begin{tabular}{lcl}
\hline Index & Range & Class \\
\hline SAR & $<10$ & Excellent \\
& $10-18$ & Good \\
& $18-26$ & Marginal \\
& $>26$ & Poor
\end{tabular}

Source: Todd (1980).

TABLE 2 | Classification of groundwater quality based on KR.

\begin{tabular}{lcl}
\hline Parameter & Range & Class \\
\hline$K R$ & $<1$ & Safe \\
& $>1$ & Unsuitable
\end{tabular}

Source: Kelly (1963).

$\mathrm{Na}^{+}$-sodium, $\mathrm{Ca}^{2+}$-calcium and $\mathrm{Mg}^{2+}$-magnesium, all in miliequivalents per liter (meq/l).

Potential salinity (PS) is another water quality index that was used to determine the salinity level based on the concentration of chloride and sulfate in the borehole water. A high concentration of chloride against sulfate builds up scales in irrigation water supply which can affect the distribution of water to crops (Vasanthavigar et al., 2010). PS is calculated and classified as follows (Table 7):

$$
\mathrm{PS}=\mathrm{Cl}^{-}+0.05 \times \mathrm{SO}_{4}^{2-}
$$

TABLE 3 | Classification of groundwater quality based on $\mathrm{Na} \%$.

\begin{tabular}{lcl}
\hline Index & Range & Class \\
\hline Na \% & $<20$ & Excellent \\
& $20-40$ & Good \\
$40-60$ & Permissible \\
$60-80$ & Doubtful \\
& $>80$ & Unsuitable
\end{tabular}

Source: Wilcox (1955).

TABLE 4 | Classification of groundwater quality based on MAR.

\begin{tabular}{lll}
\hline Parameter & Range & Class \\
\hline MAR & $<50$ & Recommended \\
& $>50$ & Not recommended
\end{tabular}

Source: Gupta and Gupta (1987) and Raghunath (1987).

where:

$\mathrm{Cl}^{-}$-chloride and $\mathrm{SO}_{4}^{2-}$-sulfate, all in miliequivalents per liter (meq/l).

\section{Statistical Analysis}

The water quality data parameters were statistically analyzed by SPSS version 26, and one-sample $T$-test was performed to determine the significance difference between groundwater and FAO (1994) guideline for irrigation water quality. 
TABLE 5 | Classification of groundwater quality based on TH.

\begin{tabular}{lcl}
\hline Parameter & Range & Class \\
\hline $\mathrm{TH}$ & $0-1.5$ & Soft \\
& $1.5-3.1$ & Moderate hard \\
& $3.1-4.6$ & Hard \\
& $>4.6$ & Very hard \\
\hline
\end{tabular}

Source: EPA (1986).

TABLE 6 | Classification of groundwater quality based on SSP.

\begin{tabular}{lcl}
\hline Parameter & Range & Class \\
\hline SSP & $<20$ & Excellent \\
& $20-40$ & Good \\
& $40-80$ & Fair \\
& $>80$ & Poor \\
\hline
\end{tabular}

Source: Joshi et al. (2009).

TABLE 7 | Classification of groundwater quality based on PS.

\begin{tabular}{lcl}
\hline Index & Range & Class \\
\hline PS & $<3$ & Suitable \\
& $>3$ & Not suitable
\end{tabular}

Source: Doneen (1964).

\section{RESULTS}

\section{Average Groundwater Parameters}

There was no statistically significant difference $(p<0.05)$ between EC, TDS, $\mathrm{Mg}^{2+}$, and FAO (1994) irrigation water standard in groundwater of all regions. However, there was a statistically significant $(p>0.05)$ difference between $\mathrm{SO}_{4}^{2-}, \mathrm{Cl}^{-}$, $\mathrm{Ca}^{2+}, \mathrm{Na}^{+}, \mathrm{K}^{+}$, and $\mathrm{FAO}$ (1994) standard for irrigation water in groundwater of all regions (Table 8 ).

The groundwater EC, TDS, and $\mathrm{Cl}^{-}$for Erongo regions, $\mathrm{Ca}^{2+}$ for Zambezi region, and $\mathrm{Mg}^{2+}$ for Ohangwena, Omaheke, and Otjozondjupa regions have exceeded the recommended irrigation water quality for FAO (1994). The groundwater $\mathrm{SO}_{4}^{2-}$ and $\mathrm{Na}^{+}$for all regions were below FAO (1994) standard for irrigation water; however, the groundwater $\mathrm{Cl}^{-}$ and $\mathrm{Ca}^{2+}$ in Hardap, Khomas, Kavango, Kunene, Karas, Ohangwena, Omaheke, Otjozondjupa, and Zambezi were below the standard, except $\mathrm{Ca}^{2+}$ in Zambezi region which exceeded the recommended guideline for water quality for Ayers and Westcot (2005). The concentration of $\mathrm{K}^{+}$in groundwater for all regions has exceeded the recommended guideline for irrigation water.

\section{Groundwater Quality Indices for Irrigation}

There is a highly significant difference in $(p>0.01)$ in groundwater quality index SAR, KR, Na\%, MAR, TH, SSP, PS, EC, and TDS for all regions (Table 9).

Sodium absorption ratio (SAR) shows that all regions have excellent $(<10 \mathrm{meq} / \mathrm{l})$ groundwater for irrigation purpose
(Table 10). KR shows that $90 \%$ of the region's groundwater is safe $(<1 \mathrm{meq} / \mathrm{l})$ for irrigation and $10 \%$ are unsuitable $(>1$ meq/l) for irrigation. The sodium percentage $(\mathrm{Na} \%)$ shows that $50 \%$ of regions' groundwater is good (range between 20 and $40 \%$ ), $40 \%$ is permissible (range between 40 and $60 \%$ ), and $10 \%$ is doubtful (range between 60 and $80 \%$ ) for irrigation. MAR shows that $70 \%$ of regions' groundwater is recommended $(<50$ $\mathrm{meq} / \mathrm{l}$ ) for irrigation and $30 \%$ of regions' groundwater is not recommended ( $>50 \mathrm{meq} / \mathrm{l})$ for irrigation. $\mathrm{TH}$ shows that all regions have very hard $(>4.6 \mathrm{meq} / \mathrm{l})$ groundwater. SSP shows that $50 \%$ of the region has excellent $(<20 \%)$ groundwater and $50 \%$ had good (range between 20-40\%) groundwater for irrigation. PS shows that all the regions' groundwater is not suitable $(>3$ $\mathrm{meq} / \mathrm{l}$ ) for irrigation. All regions' groundwater EC is very high (range between 0.75 and $2.25 \mathrm{meq} / \mathrm{l}$ ). Ninety percent (90\%) of the regions' groundwater TDS is slightly to moderate (ranges between 450 and 2,000 $\mathrm{mg} / \mathrm{l}$ ) for irrigation and $10 \%$ is unsuitable $(>2,000 \mathrm{mg} / \mathrm{l})$ for irrigation (Table 10).

\section{DISCUSSION}

TH, EC, and PS classified the groundwater samples for all regions as very hard water, having very high electrical conductivity and unsuitability for irrigation, respectively. TDS classified the groundwater for all regions as slightly moderate and unsuitable for agricultural purposes. MAR classified groundwater from Ohangwena, Omaheke, and Otjozondjupa as unsuitable for irrigation. TDS classified groundwater from Erongo region as unsuitable for agricultural purposes. TDS also classified groundwater from Hardap, Kavango, Kunene, Ohangwena, Kavango, Khomas, Karas, Omaheke, an Otjozondjupa regions as slightly to moderate for agricultural use. $\mathrm{Na}$ (\%) classified groundwater from Erongo region as doubtful for irrigation. This could be due to the higher evaporation rate and the amount of rainfall received at a specific area which has a major effect on the concentration of minerals in borehole water (Yisa et al., 2012). Heavy rainfall affects water quality by decreasing the concentration of minerals due to the high rate of infiltration, while a high evaporation rate increases the concentration of minerals, which results into the accumulation of salt in the groundwater (Hopkins et al., 2007). The decreasing and increasing of the minerals' concentration in groundwater influence the suitability of the groundwater for irrigation use.

The reason why many regions' groundwater is not suitable for irrigation could be due to the higher concentration of $\mathrm{K}^{+}$ in all regions. $\mathrm{Mg}^{2+}$ was high in Ohangwena, Omaheke, and Otjozondjipa regions. $\mathrm{Ca}^{2+}$ was high in the Zambezi region, and $\mathrm{Cl}^{-}$was high in Erongo which led to high EC and TDS in groundwater as they all exceeded the recommended guideline of FAO (1994) for water quality for irrigation.

Electrical conductivity (EC) is essential for all soluble salts in irrigation water which measures ions by an electrode (Simsek and Gunduz, 2007). It also provides an important indication of the amount of nutrients dissolved in water. Usually when it is higher or lower than the recommended value $(3 \mathrm{dS} / \mathrm{m})$, the amount of water available to crops gets lower. TDS is also an 
TABLE 8 | Average groundwater parameters.

\begin{tabular}{|c|c|c|c|c|c|c|c|c|}
\hline Regions & $\begin{array}{c}\text { EC } \\
\text { (dS/m) }\end{array}$ & $\begin{array}{c}\text { TDS } \\
(\mathrm{mg} / \mathrm{l})\end{array}$ & $\begin{array}{c}\mathrm{SO}_{4}^{2-} \\
\text { (meq/l) }\end{array}$ & $\begin{array}{c}\mathrm{Cl}^{-} \\
(\mathrm{meq} / \mathrm{l})\end{array}$ & $\begin{array}{c}\mathrm{Ca}^{2+} \\
(\mathrm{meq} / \mathrm{l})\end{array}$ & $\begin{array}{c}\mathrm{Mg}^{2+} \\
(\mathrm{meq} / \mathrm{l})\end{array}$ & $\begin{array}{c}\mathrm{Na}^{+} \\
(\mathrm{meq} / \mathrm{l})\end{array}$ & $\begin{array}{c}\mathrm{K}^{+} \\
(\mathrm{meq} / \mathrm{l})\end{array}$ \\
\hline Erongo & 4.6 & 3,005.8 & 7.3 & 31.4 & 19.5 & 3.8 & 13.8 & 5.2 \\
\hline Hardap & 2.7 & 1,695.3 & 4.8 & 16.6 & 17.4 & 1.7 & 7.4 & 1.8 \\
\hline Karas & 2.8 & 1,873.5 & 11.6 & 11.2 & 9.0 & 2.8 & 17.4 & 0.8 \\
\hline Kavango & 1.3 & 819.2 & 2.4 & 3.1 & 8.7 & 1.0 & 3.0 & 0.8 \\
\hline Khomas & 1.5 & 933.6 & 3.5 & 3.8 & 10.2 & 4.2 & 2.3 & 1.3 \\
\hline Kunene & 2.6 & $1,587.0$ & 4.3 & 12.0 & 8.5 & 4.9 & 10.1 & 1.7 \\
\hline Ohangwena & 1.5 & 978.4 & 2.1 & 2.7 & 1.6 & 12.8 & 6.4 & 0.4 \\
\hline Omaheke & 2.1 & 1,389.6 & 5.9 & 8.4 & 4.4 & 7.5 & 10.3 & 0.5 \\
\hline Otjozondjupa & 2.2 & $1,417.0$ & 7.7 & 6.4 & 4.1 & 9.1 & 10.6 & 1.0 \\
\hline Zambezi & 2.6 & $1,732.7$ & 11.6 & 11.0 & 21.0 & 1.0 & 6.6 & 1.0 \\
\hline FAO (1994) & $0-3$ & $0-2,000$ & $0-20$ & $0-30$ & $0-20$ & $0-5$ & $0-40$ & $0-0.1$ \\
\hline Mean & 2.4 & 1543.2 & 6.1 & 10.7 & 10.4 & 4.9 & 8.8 & 1.5 \\
\hline STDV & 1.0 & 629.3 & 3.4 & 8.6 & 6.7 & 3.9 & 4.7 & 1.4 \\
\hline Sig & 0.073 & 0.047 & 0.000 & 0.000 & 0.001 & 0.943 & 0.000 & 0.014 \\
\hline
\end{tabular}

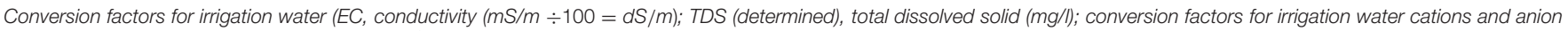

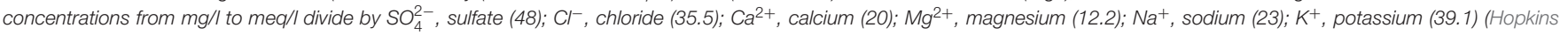
et al., 2007)).

TABLE 9 | Groundwater quality indices for irrigation in 10 regions.

\begin{tabular}{|c|c|c|c|c|c|c|c|c|c|}
\hline Regions & SAR & KR & $\mathrm{Na} \%$ & MAR & TH & SSP & PS & $\begin{array}{c}\text { EC } \\
\text { (dS/m) }\end{array}$ & $\begin{array}{c}\text { TDS } \\
\text { (mg/l) }\end{array}$ \\
\hline Erongo & 4.04 & 0.59 & 44.85 & 16.34 & 64.04 & 23.51 & 35.07 & 4.60 & $3,005.80$ \\
\hline Hardap & 2.38 & 0.38 & 32.35 & 8.98 & 50.45 & 11.31 & 19.05 & 2.72 & $1,695.35$ \\
\hline Karas & 7.13 & 1.46 & 60.56 & 23.93 & 33.90 & 22.98 & 16.94 & 2.82 & $1,873.46$ \\
\hline Kavango & 1.38 & 0.31 & 28.45 & 10.64 & 25.98 & 5.28 & 4.32 & 1.27 & 819.22 \\
\hline Khomas & 0.85 & 0.16 & 19.98 & 29.00 & 42.08 & 7.96 & 5.53 & 1.45 & 933.63 \\
\hline Kunene & 3.88 & 0.75 & 46.71 & 36.67 & 41.05 & 17.91 & 14.19 & 2.61 & $1,587.00$ \\
\hline Ohangwena & 2.37 & 0.44 & 31.82 & 88.72 & 55.20 & 23.40 & 3.72 & 1.46 & 978.42 \\
\hline Omaheke & 4.24 & 0.87 & 47.79 & 63.36 & 41.11 & 20.81 & 11.32 & 2.10 & 1,389.61 \\
\hline Otjozondjupa & 4.11 & 0.80 & 46.66 & 69.04 & 46.87 & 23.31 & 10.31 & 2.15 & $1,416.97$ \\
\hline Zambezi & 1.99 & 0.30 & 25.63 & 4.53 & 56.44 & 8.89 & 16.82 & 2.62 & $1,732.73$ \\
\hline Mean & 3.24 & 0.61 & 38.48 & 35.11 & 45.72 & 16.54 & 13.71 & 2.39 & $1,543.21$ \\
\hline STDV & 1.81 & 0.39 & 12.67 & 28.98 & 11.29 & 7.36 & 9.30 & 0.95 & 629.25 \\
\hline Sig & 0.00 & 0.00 & 0.00 & 0.00 & 0.00 & 0.00 & 0.00 & 0.00 & 0.00 \\
\hline Minimum & 0.90 & 0.20 & 20.00 & 4.50 & 26.00 & 5.30 & 3.70 & 1.30 & 819.20 \\
\hline Maximum & 7.10 & 1.50 & 60.60 & 88.70 & 64.00 & 23.50 & 35.10 & 4.60 & $3,005.80$ \\
\hline $\mathbf{N}$ & 10 & 10 & 10 & 10 & 10 & 10 & 10 & 10 & 10 \\
\hline
\end{tabular}

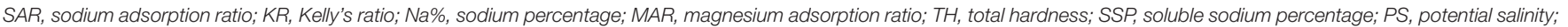
EC, conductivity; TDS (determined), total dissolved solid.

important parameter for assessing borehole water quality which measures the dissolved combined content of all inorganic and organic substances present in irrigation water. Irrigation water with high TDS $(>2,000 \mathrm{mg} / \mathrm{l})$ indicates the presence of toxic minerals, which is hazardous to plants' health. Sulfate $\left(\mathrm{SO}_{4}^{2-}\right)$ is an element commonly found in irrigation water which causes the scale buildup in irrigation water pipes and is responsible for water pollution when it exceeds the recommended amount $(>20$ meq/l). However, when it is available in a recommended amount, it dissolves other elements such as calcium and magnesium, which causes water hardness (Shah and Mistry, 2013). Chloride $\left(\mathrm{Cl}^{-}\right)$is another ion commonly found in irrigation water that is essential to crops when available at a low concentration $(>30$ $\mathrm{meq} / \mathrm{l})$. It can be toxic to sensitive crops when found in irrigation water at a high level. Normally, injury to plants begins to occur at the leaves' tips and progresses from the tips back along the edges 
TABLE 10 | Classification of groundwater quality value for irrigation in 10 regions.

\begin{tabular}{|c|c|c|c|c|}
\hline Index & Range & Class & $\%$ & Regions \\
\hline \multirow[t]{4}{*}{ SAR (meq/l) } & $<10$ & Excellent & 100 & $\begin{array}{l}\text { Erongo, Hardap, Kavango, Kunene, Ohangwena, Khomas, Otjozondjupa, } \\
\text { Zambezi and Karas }\end{array}$ \\
\hline & $10-18$ & Good & 0 & None \\
\hline & $18-26$ & Marginal & 0 & None \\
\hline & $>26$ & Poor & 0 & None \\
\hline \multirow[t]{2}{*}{ KR (meq/l) } & $<1$ & Safe & 90 & $\begin{array}{l}\text { Erongo, Hardap, Kavango, Khomas, Ohangwena, Zambezi, Kunene, } \\
\text { Ohangwena and Otjozondjupa }\end{array}$ \\
\hline & $>1$ & Unsuitable & 10 & Karas \\
\hline \multirow[t]{5}{*}{$\mathrm{Na} \%$} & $<20 \%$ & Excellent & 0 & None \\
\hline & $20-40 \%$ & Good & 50 & Ohangwena, Zambezi, Hardap, Kavango and Khomas \\
\hline & $40-60 \%$ & Permissible & 40 & Erongo, Kunene, Omaheke and Otjozondjupa \\
\hline & $60-80 \%$ & Doubtful & 10 & Karas \\
\hline & $>80 \%$ & Unsuitable & 0 & None \\
\hline \multirow[t]{2}{*}{ MAR (meq/l) } & $<50$ & Recommended for irrigation & 70 & Erongo, Kunene, Hardap, Kavango, Khomas, Karas and Zambezi \\
\hline & $>50$ & Not recommended for irrigation & 30 & Ohangwena, Omaheke and Otjozondjupa \\
\hline \multirow[t]{4}{*}{$\mathrm{TH}(\mathrm{meq} / \mathrm{l})$} & $0-1.5$ & Soft & 0 & None \\
\hline & $1.5-3.1$ & Moderate hard & 0 & None \\
\hline & $3.1-4.6$ & Hard & 0 & None \\
\hline & $>4.6$ & Very hard & 100 & $\begin{array}{l}\text { Karas, Kavango, Khomas, Kunene, Ohangwena, Omaheke, Otjozondjupa, } \\
\text { Hardap and Zambezi }\end{array}$ \\
\hline \multirow[t]{4}{*}{ SSP (\%) } & $<20$ & Excellent & 50 & Hardap, Kavango, Khomas, Kunene and Zambezi \\
\hline & $20-40$ & Good & 50 & Karas, Ohangwena, Omaheke, Otjozondjupa and Erongo \\
\hline & $40-80$ & Fair & 0 & None \\
\hline & $>80$ & Poor & 0 & None \\
\hline \multirow[t]{2}{*}{ PS (meq/l) } & $<3$ & Suitable for irrigation & 0 & None \\
\hline & $>3$ & Not suitable for irrigation & 100 & $\begin{array}{l}\text { Erongo, Karas, Kavango, Khomas, Kunene, Ohangwena, Omaheke, } \\
\text { Otjozondjupa, Hardap and Zambezi }\end{array}$ \\
\hline \multirow[t]{4}{*}{$\mathrm{EC}(\mathrm{d} S / \mathrm{m})$} & $0-0.25$ & Low & 0 & None \\
\hline & $0.25-0.75$ & Medium & 0 & None \\
\hline & $0.75-2.25$ & High & 0 & None \\
\hline & $0.75-2.25$ & Very high & 100 & $\begin{array}{l}\text { Erongo, Karas, Kavango, Khomas, Kunene, Ohangwena, Omaheke, } \\
\text { Otjozondjupa, Hardap and Zambezi }\end{array}$ \\
\hline \multirow[t]{3}{*}{ TDS (mg/l) } & $<450$ & Preferred for irrigation & 0 & None \\
\hline & $450-2,000$ & Slightly to moderate & 90 & $\begin{array}{l}\text { Hardap, Kavango, Kunene, Ohangwena, Kavango, Khomas, Karas, Omaheke, } \\
\text { Otjozondjupa }\end{array}$ \\
\hline & $>2,000$ & Unsuitable for agricultural use & 10 & Erongo \\
\hline
\end{tabular}

(Simsek and Gunduz, 2007). Calcium $\left(\mathrm{Ca}^{+}\right)$is naturally present in irrigation water. It helps with regulating ionic relations in plants and improves the soil's physical condition when available at a low concentration $(>20 \mathrm{meq} / \mathrm{l})$. When it is available in a high amount, it damages the plant's leaves' tissues, which results into a stunted plant growth. Magnesium $\left(\mathrm{Mg}^{2+}\right)$ is an important element in irrigation water which helps crops to capture the sun's energy for growth and production through photosynthesis. It is considered toxic to plants when it exceeds $>5$ meq/l. $\mathrm{Mg}^{2+}$ toxicity symptoms normally appear first on old leaves as a yellow spotting or the drying of the leave's tissue (Shah and Mistry, 2013). Sodium $\left(\mathrm{Na}^{+}\right)$is relatively important in irrigation water as it helps with water infiltration in the soil, although when it is available in high amounts $(>40 \mathrm{meq} / \mathrm{l})$ it causes hazard in the soil structure and water infiltration problem which may result into burned plant leaves, as well as scorch and dead plant tissues. Potassium $\left(\mathrm{K}^{+}\right)$detection of $\mathrm{K}^{+}$in irrigation water is quite important. $\mathrm{K}^{+}$helps with the opening and closing of stomata in plants, which regulates the uptake of carbon dioxide. When available in higher amounts $(>2 \mathrm{mg} / \mathrm{l})$, it can result in the yellowing of the foliage that first appear on the leaves' veins. Groundwater with high values of irrigation water quality index (SAR, KR, Na\%, MAR, TH, SSP, PS, EC, and TSD) are classified as unsuitable for irrigation use. This is because high values of irrigation water quality index indicate high accumulation of salt in the groundwater which affects the water quality (Rawat et al., 2018). According to Hopkins et al. (2007), water with a high salinity level affects the crop production by increasing the toxic solid materials in water, which affects the soil structure, water infiltration, soil permeability, and soil aeration. High salinity level 
can also damage the plants through an osmotic effect, which causes plants to be stressed for water and wilt even though water may be available in the soil. Excess salt in water can also burn leaf tissues when applied on leaves. It also affects the maturity of fruits from crops (Zhang et al., 2012).

\section{CONCLUSION}

In conclusion, the water quality index classified the groundwater in different regions as follows; TH, EC, and PS classified groundwater samples for all regions as very hard water, having very high electrical conductivity, and unsuitable for irrigation, respectively. TDS classified the groundwater for all regions as slightly moderate and unsuitable for agricultural purposes. MAR classified groundwater from Ohangwena, Omaheke, and Otjozondjupa as unsuitable for irrigation. TDS classified groundwater from Erongo region as unsuitable for agricultural purposes. TDS also classified groundwater from Hardap, Kavango, Kunene, Ohangwena, Kavango, Khomas, Karas, Omaheke, and Otjozondjupa regions as slightly to moderate for agricultural use. Na (\%) classified groundwater from Erongo region as doubtful for irrigation. The results were due to higher a concentration of $\mathrm{K}^{+}$in all regions. $\mathrm{Mg}^{2+}$ was high in Ohangwena, Omaheke, and Otjozondjipa regions. $\mathrm{Ca}^{2+}$ was high in Zambezi region and $\mathrm{Cl}^{-}$was high in Erongo region which exceeded the recommended guideline of FAO (1994) for water quality for irrigation. The higher $\mathrm{K}^{+}, \mathrm{Mg}^{2+}, \mathrm{Ca}^{2+}$, and $\mathrm{Cl}^{-}$ in groundwater also contributed to high EC and TDS.

Other water quality indexes such as $\mathrm{Na}$ (\%) had inverse classification and classified groundwater from Ohangwena, Zambezi, Hardap, Kavango, and Khomas of regions as good, and groundwater from Erongo, Kunene, Omaheke, and Otjozondjupa as permissible for irrigation. SSP classified groundwater for all regions as excellent and good, and MAR

\section{REFERENCES}

Akpan-Idiok, A. U., Ibrahim, A., and Udo, I. A. (2012). Water quality assessment of Okpauku river for drinking and irrigation uses in Yala, Cross river state, Nigeria. Res. J. Environ. Sci. 6:210. doi: 10.3923/rjes.2012.210.221

Ayers, R. S., and Westcot, D. W. (2005). Water Quality for Agriculture, Vol. 29. Rome: Food and Agriculture Organization of the United Nations.

Bauder, J. W., Bauder, T. A., Waskom, R. M., and Scherer, T. F. (2008). Assessing the Suitability of Water (Quality) for Irrigation-Salinity and Sodium. Western Fertilizer Handbook.

Bhat, M. A., Grewal, M. S., Rajpaul, R., Wani, S. A., and Dar, E. A. (2016). Assessment of groundwater quality for irrigation purposes using chemical indices. Indian J. Ecol. 43, 574-579.

Bucks, D. A., Nakayama, F. S., and Gilbert, R. G. (2009). Trickle irrigation water quality and preventive maintenance. Agric. Water Manag. 2, 149-162. doi: 10.1016/0378-3774(79)90028-3

Christelis, G., and Struckmeier, W. (2011). Groundwater in Namibia: An Explanation to the Hydrogeological Map, 2nd Edn. Cape Town: Department of Water Affairs, Ministry of Agriculture, Water and Rural Development; The Geological Survey of Namibia, Ministry of Mines and Energy; The Namibia Water Corporation and the Federal Institute for Geoscience and Natural Resources on behalf of the German Ministry of Economic Cooperation and Development. classified groundwater from Erongo, Kunene, Hardap, Kavango, Khomas, Karas, and Zambezi as recommended for irrigation. KR classified groundwater from Erongo, Hardap, Kavango, Khomas, Ohangwena, Zambezi, Kunene, Ohangwena, and Otjozondjupa regions as safe for irrigation and SAR classified all regions' groundwater as excellent for irrigation.

\section{DATA AVAILABILITY STATEMENT}

The raw data supporting the conclusions of this article will be made available by the authors, without undue reservation.

\section{AUTHOR CONTRIBUTIONS}

HA: conceptualization, supervision, and write up. NK: conceptualization and contribution to write up. LK: analysis and write up for Hardap region. All authors contributed to the article and approved the submitted version.

\section{FUNDING}

The grant of 1150 USD is provided by North West University for publication.

\section{ACKNOWLEDGMENTS}

The authors acknowledge in-kind support from the North-West University, Ministry of Agriculture Water and Land Reform in Namibia, Namibia University of Science and Technology, the UNESCO Chair on Sustainable Water Research for Climate Adaptation in Arid Environments, and the borehole distribution map produced by Dr. Tendai Nzuma from Namibia University of Science and Technology.

Doneen, L. D. (1964). "Notes on water quality in agriculture," in Published as a Water Science and Engineering, Department of Water Sciences and Engineering, University of California, Davis, Paper 4001.

FAO (1994). "Water quality for agriculture" in Irrigation and Drainage Paper, eds S. R. Ayers, and W. D. Westcot. Available online at: http://www.fao.org/3/t0234e/ t0234e00.htm (accessed July 17, 2021).

Gupta, S. K., and Gupta, I. C. (1987). Management of Saline Soils and Water. New Delhi: Oxford and IBH publication Co., 399.

Hopkins, B. G., Horneck, D. A., Stevens, R. G., Ellsworth, J. W., and Sullivan, D. M. (2007). Managing Irrigation Water Quality for Crop Production in the Pacific Northwest. (Oregon State: Pacific North West Extension publication).

Jaji, M. O., Bamgbose, O., Odukoya, O. O., and Arowolo, T. A. (2007). Water quality assessment of Ogun River, southwest Nigeria. Environ. Monit. Asses. 133, 473-482. doi: 10.1007/s10661-006-9602-1

Jannis, E., Adrien, M., Affolter, A., and Huggenberger, P. (2021). Climate change effects on groundwater recharge and temperatures in Swiss alluvial aquifers. J. Hydrol. 11: 100071. doi: 10.1016/j.hydroa.2020.100071

Joshi, D. M., Kumar, A., and Agrawal, N. (2009). Assessment of the irrigation water quality of river Ganga in Haridwar District India. J. Chem. 2, 285-292.

Kelly, W. P. (1963). Use of saline irrigation water. Soil Sci. 95, 355-391. doi: 10.1097/00010694-196306000-00003

Meireles, A. C. M., Andrade, E. M. D., Chaves, L. C. G., Frischkorn, H., and Crisostomo, L. A. (2010). A new proposal of the 
classification of irrigation water. Rev. Ciência Agron. 41, 349-357. doi: 10.1590/S1806-66902010000300005

NamWater (2021). Hydrological Services. Available online at: https://www. namwater.com.na/index.php/services/56-hydrological-services?showall=1 (accessed July 17, 2021).

Raghunath, H. M. (1987). Groundwater. New Delhi: Wiley Eastern Ltd., 344-369.

Rawat, K. S., Singh, S. K., and Gautam, S. K. (2018). Assessment of groundwater quality for irrigation use: a peninsular case study. Appl. Water Sci. 8:233. doi: 10.1007/s13201-018-0866-8

Shah, S. M., and Mistry, N. J. (2013). Groundwater quality assessment for irrigation use in Vadodara District, Gujarat, India. World Acad. Sci. Eng. Tech. 23, 7-23. doi: 10.9790/2402-0724650

Simsek, C., and Gunduz, O. (2007). IWQ index: a GIS-integrated technique to assess irrigation water quality. Environ. Monit. Asses. 128, 277-300. doi: 10.1007/s10661-006-9312-8

Stefan, L., Kramm, J., Jokisch, A., and Mller, K. (2008). Edited: Integrated Water Resources Management in Water-Scarce Regions: Water Harvesting, Groundwater Desalination and Water Reuse in Namibia. Chapter 2: Conditions and Challenges of Namibia's Water Resources Management. IWA Publishing.

Todd, D. K. (1980). Groundwater Hydrology, 2nd Edn. New York, NY: Wiley, 535.

United States Environmental Protection Agency (U.S. EPA) (1986). Quality criteria for water 1986, EPA 440/5-86-001.

Vasanthavigar, M., Srinivasamoorthy, K., Vijayaragavan, K., Ganthi, R. R., Chidambaram, S., Anandhan, P., et al. (2010). Application of water quality index for groundwater quality assessment: Thirumanimuttar sub-basin, Tamilnadu, India. Environ. Monit. Assess. 171, 595-609. doi: 10.1007/s10661-009-1302-1
Wilcox, L. V. (1955). Classification and Use of Irrigation Waters. USD Circular No. 969, (Washington D.C.: United State Department of Agriculture), 19.

Yisa, J., Jimoh, T. O., and Oyibo, O. M. (2012). Underground water assessment using water quality index. Leonardo J. Sci. 21, 33-42.

Zhang, B., Song, X., Zhang, Y., Han, D., Tang, C., Yu, Y., et al. (2012). Hydrochemical characteristics and water quality assessment of surface water and groundwater in Songnen plain, Northeast China. Water Res. 46, 2737-2748. doi: 10.1016/j.watres.2012.02.033

Conflict of Interest: The authors declare that the research was conducted in the absence of any commercial or financial relationships that could be construed as a potential conflict of interest.

Publisher's Note: All claims expressed in this article are solely those of the authors and do not necessarily represent those of their affiliated organizations, or those of the publisher, the editors and the reviewers. Any product that may be evaluated in this article, or claim that may be made by its manufacturer, is not guaranteed or endorsed by the publisher.

Copyright (C) 2021 Amwele, Kgabi and Kandjibi. This is an open-access article distributed under the terms of the Creative Commons Attribution License (CC BY). The use, distribution or reproduction in other forums is permitted, provided the original author(s) and the copyright owner(s) are credited and that the original publication in this journal is cited, in accordance with accepted academic practice. No use, distribution or reproduction is permitted which does not comply with these terms. 